\title{
Evaluation of Coupling Coordination Degree between Urbanization and Agricultural Modernization*
}

\author{
Qi Shen \\ Chongqing Academy of Agricultural Sciences \\ Chongqing, China 401329
}

\author{
Xiaoqun $\mathrm{Hu}$ \\ Chongqing Academy of Agricultural Sciences \\ Chongqing, China 401329
}

\begin{abstract}
On the basis of explaining the coupling mechanism of urbanization and agricultural modernization, according to the principles of humanism, coordination between urbanization and agricultural modernization, this paper uses the spatial description method to establish the model of coupling coordination degree between the two, and to carry out the empirical study on the coupling coordination between urbanization and agricultural modernization regarding the $\mathbf{1 6}$ provinces in the eastern, western, central and northeast regions as the example. The results show that, from 2000 to 2015, the coupling degree of the two in China is increased from 0.1612 to $\mathbf{0 . 7 3 3 3}$, which is changed from high degree of misalignment to intermediate coupling coordination, and the coordinated development of the two is improved greatly. From the regional perspective, the coupling coordination degree of the four regions shows the distribution of "the east occupies first place, the center comes second, the west third and the northwest the last". The differences in the development of the provinces are narrowing with a convergence trend for $\sigma$ value. There is a clear positive correlation between the coordination degree of urbanization and agricultural modernization and the level of regional economic development.
\end{abstract}

Keywords-urbanization; agricultural modernization; coupling coordination degree; $\sigma$ convergence

\section{INTRODUCTION}

New urbanization is an important issue to build China's economic upgrading and to promote the transformation of economic and social structure. Agricultural modernization is the only way for China's agricultural and rural economic development. The new urbanization is the urbanization essentially featuring urban and rural coordination, urban and rural integration, industry-city interaction, intensive conservation, ecological livability and harmonious development, and the one featuring a coordinated development of small, medium and large-sized cities, small towns and new rural communities in a mutual promoting relationship. The new urbanization is also focused on farmers, covering rural areas and emphasizing the coordinated and synchronous development in towns and countries, which is different from the one-sided emphasis on urban construction for the traditional urbanization.

*Fund Project: Chongqing's innovation topic in decision-making advisory and management: The Improvement Measures for the Supply Efficiency of Agricultural Products in Chongqing: Research Perspective of Supply-side Reform(cstc2016jccxBX0019)
According to the system theory, coordination is the harmonious symbiosis of each subsystem in a multiplexed system in the process of development and evolution. The degree of coordination between urbanization and agricultural modernization refers to the degree of harmony between the two in the development process [1].Well-promoted and wellcoordinated urbanization and agricultural modernization lead to modern elements implanting to the agricultural field, and to support urban construction industry, which is more able to promote the virtuous circle between urbanization and agricultural modernization. Therefore, it is of great significance to study the coordination relationship between urbanization and agricultural modernization, to explore the influencing factors of the coordination degree between the two, and to analyze the differences in regional development, so as to promote the simultaneous development of the two [2].

The level of comprehensive development in China's various regions vary greatly, and the degree of coordinated development between urbanization and agricultural modernization varies from time and place, which largely determines the proper direction and path of regional urban layout planning and agricultural industry policy adjustment. In order to further clarify the development trend of urbanization and agricultural modernization in each region, to definite the regional functional orientation and to determine the differentiated development strategy, this paper combines the basis of regional natural resources with the stage difference of economic and social development, on the basis of the interpretation on coupling mechanism of urbanization and agricultural modernization, so as to establish the model of coupling coordination degree of the two, to carry out the empirical study regarding the 16 provinces in the eastern, western, central and northeast regions as the example, and to evaluate and analyze the degree of coupling coordination between the two in each region from 2000 to 2015 with the aim of providing a scientific basis for the relevant policy development. 


\section{EVALUATION INDEX SYSTEM CONSTRUCTION OF THE COORDINATION DEGREE BETWEEN URBANIZATION AND AGRICULTURAL MODERNIZATION}

TABLE I. EVALUATION INDICATOR SYSTEM OF COORDINATED DEVELOPMENT BETWEEN URBANIZATION AND AGRICULTURAL MODERNIZATION

\begin{tabular}{|c|c|c|c|c|c|}
\hline $\begin{array}{l}\text { Aggregative } \\
\text { Indicator }\end{array}$ & Main Indicator & $\begin{array}{c}\text { Classification } \\
\text { Indicator }\end{array}$ & Individual Indicator & Unit & $\begin{array}{l}\text { Indicator } \\
\text { Property }\end{array}$ \\
\hline \multirow{32}{*}{$\begin{array}{l}\text { Coordinated } \\
\text { development of } \\
\text { urbanization and } \\
\text { agricultural } \\
\text { development }\end{array}$} & \multirow{20}{*}{ Urbanization } & \multirow{3}{*}{$\begin{array}{l}\text { Economic } \\
\text { Development }\end{array}$} & GDP per capita & $\begin{array}{l}\text { Yuan per } \\
\text { person }\end{array}$ & Positive \\
\hline & & & GDP growth speed & $\%$ & Positive \\
\hline & & & $\begin{array}{l}\text { Proportion of total output value of tertiary } \\
\text { sector }\end{array}$ & $\%$ & Positive \\
\hline & & \multirow{2}{*}{$\begin{array}{l}\text { Level of } \\
\text { Urbanization }\end{array}$} & Urban population & $\begin{array}{l}0,000 \\
\text { people }\end{array}$ & Positive \\
\hline & & & Urbanization rate & $\%$ & Positive \\
\hline & & \multirow{3}{*}{ Employment } & Employment proportion of urban population & $\%$ & Positive \\
\hline & & & Registered unemployment rate of urbanization & $\%$ & Negative \\
\hline & & & Social employees & $\begin{array}{l}0,000 \\
\text { people }\end{array}$ & Positive \\
\hline & & \multirow{3}{*}{ People's Livelihood } & $\begin{array}{l}\text { Per-capita Disposable Income of Urban } \\
\text { Residents }\end{array}$ & yuan & Positive \\
\hline & & & Engel coefficient of urban households & $\%$ & Negative \\
\hline & & & Per-capita housing area inurban areas & $\begin{array}{l}\text { square } \\
\text { meter }\end{array}$ & Positive \\
\hline & & \multirow{5}{*}{ Infrastructure } & Per-capita public green area in urban areas & $\begin{array}{l}\text { square } \\
\text { meter }\end{array}$ & Positive \\
\hline & & & Per-capita urban road area & $\begin{array}{l}\text { square } \\
\text { meter }\end{array}$ & Positive \\
\hline & & & Green coverage rate of built-up area & $\%$ & Positive \\
\hline & & & Water-use popularity rate & $\%$ & Positive \\
\hline & & & Gas-use popularity rate & $\%$ & Positive \\
\hline & & \multirow{4}{*}{ Social Security } & Health manpower every ten thousand people & person & Positive \\
\hline & & & $\begin{array}{l}\text { Proportion of urban residents with minimum } \\
\text { living allowance accounting for the total non- } \\
\text { agricultural people }\end{array}$ & $\%$ & Positive \\
\hline & & & $\begin{array}{l}\text { Coverage of convenient service network every } \\
\text { thousand }\end{array}$ & $\%$ & Positive \\
\hline & & & $\begin{array}{l}\text { Proportion of insured urban employees in basic } \\
\text { medical insurance }\end{array}$ & $\%$ & Positive \\
\hline & \multirow{12}{*}{$\begin{array}{l}\text { Agricultural } \\
\text { Modernization }\end{array}$} & \multirow{4}{*}{ Agricultural Input } & Fiscal expenditure on agriculture & $\begin{array}{l}-0,000 \\
\text { yuan }\end{array}$ & Positive \\
\hline & & & Employees of primary sector & $\begin{array}{l}0,000 \\
\text { people }\end{array}$ & Positive \\
\hline & & & Sown area of crops & $\begin{array}{l}0,000 \\
\text { hectare }\end{array}$ & Positive \\
\hline & & & Effective irrigation area & $\begin{array}{l}-0,000 \\
\text { hectare }\end{array}$ & Positive \\
\hline & & \multirow{4}{*}{ Agricultural Output } & $\begin{array}{l}\text { Proportion of total output value of primary } \\
\text { sector }\end{array}$ & $\%$ & Positive \\
\hline & & & Total powers of agricultural machinery & _0,000 KW & Positive \\
\hline & & & Grain yield per hectare & $\mathrm{Kg} / \mathrm{Ha}$ & Positive \\
\hline & & & Per-capita grain output & $\mathrm{Kg}$ & Positive \\
\hline & & \multirow{3}{*}{ Farmers' Livelihood } & Engel coefficient of rural households & $\%$ & Negative \\
\hline & & & Per-capita net income of farmers & $\begin{array}{l}\text { Yuan per } \\
\text { person }\end{array}$ & Positive \\
\hline & & & Per-capita housing area in rural areas & $\begin{array}{l}\text { square } \\
\text { meter }\end{array}$ & Positive \\
\hline & & $\begin{array}{l}\text { Agroecological } \\
\text { Environment }\end{array}$ & Forest coverage rate & $\%$ & Positive \\
\hline
\end{tabular}

\section{A. Index System Setting}

On the basis of fully understanding the connotation and characteristics of the new urbanization and agricultural modernization, and the in-depth analysis of the existing researches, this paper selects the evaluation indexes respectively from the two subsystems of urbanization and agricultural modernization, and establishes the coupling coordination index system between the two. In the selection of indexes, in addition to following the general principles of index selection, the urbanization indexes focus on reflecting the people-oriented, and coordinating with agricultural modernization, so as to achieve urban and rural overall and sustainable development, therefore, employment, people's lives, social security and other indexes are selected. The indexes of agricultural modernization reflect the 
improvements of agricultural input-output and the living conditions of rural residents, so agricultural expenditure, grain yield per hectare, rural residents' Engel coefficient and other indexes are selected. The index system includes 1 comprehensive index, 2 main indexes, 10 classification indexes, 34 individual indexes, of which 29 forward indexes and 3 reverse indexes. The first level: comprehensive indexes, reflecting the integration of urbanization and agricultural modernization as a whole. The second level: the

\section{B. Data Sources and Standardized Processing}

The index values in this paper are mainly derived from the China Statistical Yearbook, China Urban Statistical Yearbook, China Agricultural Statistical Yearbook, China Rural Statistical Yearbook, regional statistical yearbooks, annual reports of statistics and websites with related information statistics. For some years, the individual index values are missing, so this paper uses the moving average method and exponential smoothing method to complement them.

As the 32 indexes in Table 1 contain both forward and reverse indexes with differences in the dimension and the lack of comparability, resulting in significant differences between the data, this paper chooses the maximum difference normalization method to standardize the original data of the indexes, in order to eliminate the incompatibility caused by dimension differences.

Suppose there is m plan(s) to be evaluated (in this article, it refers to the year) and $\mathrm{n}$ evaluation index(es), so as to respectively form the data matrix of original index $\mathrm{Z}=\left(\mathrm{z}_{\mathrm{ij}}\right)_{\mathrm{mxn}}$, of which $\mathrm{z}_{\mathrm{ij}}$ means the index value of $\mathrm{i}$ as a ranking object under the index of $j$. The indexes in each matrix is normalized according to the following two cases to get a normalization matrix $\mathrm{R}=\left(\mathrm{r}_{\mathrm{ij}}\right)_{\operatorname{m\times n}}, \mathrm{r}_{\mathrm{ij}} \in[0,1]$. The specific formula is as follows:

When ${ }^{z_{i j}}$ is the forward index, that is, the bigger the index, the better the status,

$$
\mathrm{r}_{\mathrm{ij}}=\frac{\mathrm{z}_{\mathrm{ij}}-\mathrm{z}_{\text {min }}}{\mathrm{z}_{\text {max }}-\mathrm{z}_{\text {min }}}
$$

When $\mathrm{Z}_{\mathrm{ij}}$ is thereverse index, that is, the smaller the index, the better the status,

$$
\mathrm{r}_{\mathrm{ij}}=\frac{\mathrm{z}_{\max }-\mathrm{z}_{\mathrm{ij}}}{\mathrm{z}_{\max }-\mathrm{z}_{\text {min }}}
$$

Of which, zmax and zmin are the best or the worst in the different objects under the same evaluation index, respectively. For the data after the dimensionless processing within the range of $[0,1]$, for both the forward index and the reverse index, the bigger value of $\mathrm{r}_{\mathrm{ij} \text { is }}$ the better.

\section{Index Empowerment Method}

In order to minimize the subjective consciousness of weight determination, this paper uses principal component analysis to determine the weights of indexes in the two subsystems respectively, because the dimension-reducing main indexes, reflecting the development degree respectively from the two subsystems of urbanization and agricultural modernization. The third level: classification indexes, plays a connecting role between the preceding and the following in the entire index system, reflecting the main content in the basic level of the upper indexes. The fourth level: individual indexes, reflecting the basic content of classification indexes, and measuring each specific index of the coordination degree with a total of 32 small items [3], see "Table I".

technology of principal component analysis can better solve the requirements of multi-index evaluation, and the used information weight is generated with the mathematical transformation process in the multi-index comprehensive evaluation, which cannot be adjusted artificially, so as to avoid the arbitrariness of subjective assignment.

In this paper, SPSS 23.0 software is used to determine the weight by principal component analysis, in order to obtain the comprehensive development index of urbanization and agricultural modernization subsystems. The comprehensive development level index reflects the relative development level of each subsystem in the evaluation system and the bigger the index, the higher the relative development level. In the principal component analysis, the development indexes of each subsystem are numerically equivalent and comparable. The index weight obtained by this method is equal to the variance contribution rate of the principal component. The calculation steps are as follows:

The first step is to compute the correlation coefficient matrix. Use the Jacobi method to get the Eigen value and the eigenvector. Eigen values are the variance of principal components, and their sizes reflect the influence of each principal component.

The second step is to calculate the coefficient of principal component score and the contribution rate of cumulative variance. According to the principle that the component Eigen values of the elements are greater than 1 and the contribution rate of cumulative variance is greater than $80 \%$, the number of principal components is determined, so as to extract the principal component and the score coefficient matrix of the subsystem.

The third step is to calculate the score values of main components. The principal component scores of the urbanization subsystem and the agricultural modernization subsystem are obtained respectively by that the score coefficient of main component score multiplies by the normalized value corresponding to the original variable to get a summation.

The fourth step is to calculate the comprehensive development index of each subsystem. The comprehensive development indexes of the urbanization subsystem and the agricultural modernization subsystem are obtained by summing the contribution rate of variance as a weight and the score value of corresponding principal components after their multiplication.

Similarly, the comprehensive development index of urbanization and agricultural modernization subsystems in other regions from 2000 to 2015 is obtained. 


\section{Construct a Model of Coupling Coordination Degree}

1) The definition of coupling degree and coupling coordination degree: Coupling was originally used in physics to describe the phenomenon that two or more systems influencing each other by a certain interaction. The coupling degree is used to reflect the degree of interaction and mutual influence between the systems, so the coupling degree between urbanization and agricultural modernization is to measure the degree of interrelationship and mutual cooperation between the two. When the urbanization and agricultural modernization with a proper coordination and mutual promotion, known as benign coupling, the coupling value is higher; when the two constraints and conflicts each other, known as the vicious coupling, the coupling value is lower accordingly.

Coupling coordination is a benign relationship between the systems, as a result of a virtuous circle generated by a proper and harmonious cooperation for the elements within the system in the development process. Coupling coordination degree is used to reflect the degree of harmony in the development of the system, and then the coupling coordination degree between urbanization and agricultural modernization is to measure the degree of coherence in their development process. If one of subsystems has a rapid development, at the same time, another subsystem is also gradually developed, it is a better embodiment of coupling coordination, on the contrary, it is not coordinated. Coupling coordination degree not only takes into account the degree of interaction between urbanization and agricultural modernization, but also examines the level of development between the two, that is, the simultaneous and developing degrees of the two also are paid attention [4].

2) Evaluation function of coupling coordination degree: By applying the coupling concept of physics to the field of economics and using the coupling coefficient model, scholars have created calculation models of the system coordination degree based on the idea of minimizing the deviations between subsystems. Among them, the model proposed by Liao Chongbin is widely used because of its rigorous logic and accurate expression of the coordination degree between the interconnected systems. Application of it in the dual system of urbanization and agricultural modernization is as follows:

Supposing that in a certain period $\mathrm{T}$, subsystem $\mathrm{A}$ and subsystem $B$ run to a certain state, the space position of $A$ and $\mathrm{B}$ can be described as MA and MB (MA and MB represent respectively specific sequence values of the comprehensive evaluation index of urbanization and agricultural modernization). According to the calculation method of spatial distance, the coupling degree evaluation model of the two systems can be defined as follows[5]:

$$
\begin{aligned}
& M_{A B}=\left(M_{A}+M_{B}\right) / 2 \\
& \mathrm{C}=\sqrt{\frac{M_{A} \times M_{B}}{M_{A B}^{2}}}
\end{aligned}
$$

In (3) and (4), $C$ is the coupling degree of system $A$ and system $\mathrm{B}$ in time $\mathrm{T}$. MA and $\mathrm{MB}$ represent respectively the development level of urbanization and agricultural modernization while MAB is the average development level of the two systems. It is obvious that the coupling degree $\mathrm{C}$ is between 0 and 1 . When it is close to 1 , the two systems achieve a good resonant coupling state, and interaction between them is the strongest; When it is close to 0 , the two are in a state of disordered development, and there is no interaction and even antagonistic effect between factors of the two systems[6].

Although the coupling degree $\mathrm{C}$ can measure the interaction strength between agricultural modernization and urbanization, it is difficult to reflect the level of overall coordinated development of the system. For example, when the development level of each subsystem is low, higher coupling degree can also be obtained by using this model, which is confused with the higher coupling degree when the development level of each subsystem is higher. In order to accurately evaluate the coupling coordination degree between urbanization and agricultural modernization, it is necessary to construct the system coupling coordination degree model.

The coupling coordination degree is to measure the degree of harmony between systems in the course of development. In addition to considering the interaction strength between systems, it also pays close attention to the development level of each system and measures the degree of synchronization and development of agricultural modernization and urbanization.

$$
\begin{aligned}
& \mathrm{T}=\alpha M_{A}+\beta M_{B} \\
& \mathrm{D}=\sqrt{C T}
\end{aligned}
$$

In (5) and (6), D is the coupling coordination degree and $\mathrm{C}$ is the coupling degree. $\mathrm{T}$ indicates the comprehensive evaluation index of urbanization and agricultural modernization, which reflects the overall synergy effect of two subsystems. $A$ and $\beta$ are pending parameters determined by importance of the subsystem. In this paper, the author holds the view that urbanization is as important as agricultural modernization, so $\alpha=\beta=0.5$ is taken.

3) Evaluation criteria of coupling coordination degree: On the basis of the existing research results, coupling coordination between urbanization and agricultural modernization, in accordance with its level, is divided into three major types and ten $M^{\text {sub-types; according to }}$ comparison between $M_{A}$ and $M_{B}$ which are respectively referred to the comprehensive evaluation index of urbanization and agricultural modernization, every subtypes can be divided into three types, thus forming 30 basic types[7], which is shown as "Table II". 
TABLE II. ClassificATION System AND ASSESSMENT CRITERIA of MODERNIZATION COUPLING COORDINATION BETWEEN URBANIZATION AND AGRICULTURAL MODERNIZATION

\begin{tabular}{|l|l|l|l|}
\hline \multicolumn{1}{|c|}{ Types } & Level & \multicolumn{1}{c|}{ Range } & \multicolumn{1}{c|}{ Sub-types } \\
\hline \multirow{4}{*}{ ImbalancedDecay (unaccepted range) } & 1 & $0.0000-0.1000$ & Extremely imbalanced Decay \\
\cline { 2 - 4 } & 2 & $0.1000-0.2000$ & High-level imbalanced Decay \\
\cline { 2 - 4 } & 3 & $0.2000-0.3000$ & Moderate imbalanced Decay \\
\cline { 2 - 4 } & 4 & $0.3000-0.4000$ & Low-level imbalanced Decay \\
\hline \multirow{2}{*}{$\begin{array}{l}\text { Low-level Coordination } \\
\text { (narrowly accepted range) }\end{array}$} & 5 & $0.4000-0.5000$ & On the Verge of imbalanced Decay \\
\cline { 2 - 4 } $\begin{array}{l}\text { Moderate Coordination } \\
\text { (accepted range) }\end{array}$ & 6 & $0.5000-0.6000$ & Forced Coupling Coordination \\
\hline \multirow{2}{*}{$\begin{array}{l}\text { High-level Coordination } \\
\text { (accepted range) }\end{array}$} & 7 & $0.6000-0.7000$ & Primary Coupling Coordination \\
\cline { 2 - 4 } & 8 & $0.7000-0.8000$ & Moderate Coupling Coordination \\
\cline { 2 - 4 } & 9 & $0.8000-0.9000$ & Good Coupling Coordination \\
\hline
\end{tabular}

\section{EMPIRICAL ANALYSIS OF COUPLING COORDINATION}

DEGREE BETWEEN URBANIZATION AND AGRICULTURAL

\section{MODERNIZATION}

\section{A. Measure and Calculation of Coupling Coordination Degree}

This paper takes sixteen representative provinces from East China, West China, Central China, and Northeast China and builds on the data from 2000 to 2015 . With the help of software of SPSS 23.0, it firstly has original data engaged in the process of standardization by the extremum method; secondly, has principal components extracted under the principal component analysis to obtain comprehensive development index of the subsystems of urbanization and agricultural modernization; finally, calculates coupling coordination degree of urbanization and agricultural modernization [8].

This study makes the following definitions: $M$ stands for comprehensive evaluation index (specifically, $M_{A}$ is referred to urbanization and $M_{B}$ represents agricultural modernization); $\omega_{\mathrm{j}}$ for weight value of No. $\mathrm{J}_{\text {indicator }}, \mathrm{r}_{\mathrm{ijf}}$ indicator value after dimensionless processing; $\mathrm{n}$ for the number of evaluation indicator. Besides, the following weighting function formula is employed to make the evaluation function. From the above descriptions, we can draw the comprehensive evaluation index of urbanization.

$$
M=\sum_{\mathrm{j}=1}^{\mathrm{n}} \omega_{\mathrm{j}} \mathrm{r}_{\mathrm{ij}},(\mathrm{j}=1,2, \cdots, \mathrm{n})
$$

Therefore, comprehensive evaluation index theoretically is ranging from 0 to 1 , smaller one indicating weaker development capacity and vice versa. $M_{A_{-}} M_{B}>0$ means that urbanization is lagging behind agricultural modernization; $M_{A-} M_{B}=0$ stands for the synchronous development between urbanization and agricultural modernization[9]. $M_{A_{-}} M_{B}<0$ represents that agricultural modernization is lagging behind urbanization. By substituting the indicator and weight values of their subsystems into the above evaluation function, we can figure out the evaluation results of nationwide coupling coordination between urbanization and agricultural modernization from 2005 to 2015 , which is shown as "Table III".

TABLE III. COUPLING COORDINATION DEGREE OF URBANIZATION AND AGRICULTURAL MODERNIZATION ACROSS THE COUNTRY FROM 2000 TO 2015

\begin{tabular}{|c|c|c|c|c|c|c|c|c|c|c|c|c|c|c|c|c|}
\hline Year & 2000 & 2001 & 2002 & 2003 & 2004 & 2005 & 2006 & 2007 & 2008 & 2009 & 2010 & 2011 & 2012 & 2013 & 2014 & 2015 \\
\hline Jiangsu & 0.2597 & $\begin{array}{l}0.167 \\
6\end{array}$ & $\begin{array}{l}0.109 \\
0\end{array}$ & $\begin{array}{l}0.288 \\
8\end{array}$ & $\begin{array}{l}0.249 \\
4\end{array}$ & $\begin{array}{l}0.389 \\
4\end{array}$ & $\begin{array}{l}0.541 \\
7\end{array}$ & $\begin{array}{l}0.589 \\
0\end{array}$ & $\begin{array}{l}0.630 \\
4\end{array}$ & $\begin{array}{l}0.694 \\
0\end{array}$ & $\begin{array}{l}0.776 \\
7\end{array}$ & $\begin{array}{l}0.815 \\
7\end{array}$ & $\begin{array}{l}0.827 \\
0\end{array}$ & $\begin{array}{l}0.863 \\
8\end{array}$ & $\begin{array}{l}0.878 \\
5\end{array}$ & $\begin{array}{l}0.892 \\
9\end{array}$ \\
\hline Zhejiang & 0.4717 & $\begin{array}{l}0.206 \\
5 \\
\end{array}$ & $\begin{array}{l}0.318 \\
3 \\
\end{array}$ & $\begin{array}{l}0.236 \\
8 \\
\end{array}$ & $\begin{array}{l}0.495 \\
8\end{array}$ & $\begin{array}{l}0.560 \\
5 \\
\end{array}$ & $\begin{array}{l}0.608 \\
6 \\
\end{array}$ & $\begin{array}{l}0.656 \\
2 \\
\end{array}$ & $\begin{array}{l}0.696 \\
5 \\
\end{array}$ & $\begin{array}{l}0.749 \\
8\end{array}$ & $\begin{array}{l}0.782 \\
6 \\
\end{array}$ & $\begin{array}{l}0.827 \\
9\end{array}$ & $\begin{array}{l}0.844 \\
1\end{array}$ & $\begin{array}{l}0.857 \\
0\end{array}$ & $\begin{array}{l}0.864 \\
5\end{array}$ & $\begin{array}{l}0.871 \\
8\end{array}$ \\
\hline Fujian & 0.3371 & $\begin{array}{l}0.149 \\
6\end{array}$ & $\begin{array}{l}0.243 \\
8\end{array}$ & $\begin{array}{l}0.278 \\
7\end{array}$ & $\begin{array}{l}0.381 \\
0\end{array}$ & $\begin{array}{l}0.463 \\
2\end{array}$ & $\begin{array}{l}0.541 \\
9\end{array}$ & $\begin{array}{l}0.583 \\
7\end{array}$ & $\begin{array}{l}0.622 \\
9\end{array}$ & $\begin{array}{l}0.670 \\
0\end{array}$ & $\begin{array}{l}0.739 \\
9\end{array}$ & $\begin{array}{l}0.766 \\
0\end{array}$ & $\begin{array}{l}0.760 \\
8\end{array}$ & $\begin{array}{l}0.834 \\
2\end{array}$ & $\begin{array}{l}0.837 \\
7\end{array}$ & $\begin{array}{l}0.841 \\
0\end{array}$ \\
\hline Shandong & 0.1883 & $\begin{array}{l}0.261 \\
1\end{array}$ & $\begin{array}{l}0.096 \\
1\end{array}$ & $\begin{array}{l}0.282 \\
9\end{array}$ & $\begin{array}{l}0.347 \\
4\end{array}$ & $\begin{array}{l}0.388 \\
4\end{array}$ & $\begin{array}{l}0.483 \\
2\end{array}$ & $\begin{array}{l}0.553 \\
3\end{array}$ & $\begin{array}{l}0.604 \\
8\end{array}$ & $\begin{array}{l}0.639 \\
4\end{array}$ & $\begin{array}{l}0.693 \\
3\end{array}$ & $\begin{array}{l}0.732 \\
1\end{array}$ & $\begin{array}{l}0.765 \\
7\end{array}$ & $\begin{array}{l}0.783 \\
4\end{array}$ & $\begin{array}{l}0.813 \\
5\end{array}$ & $\begin{array}{l}0.807 \\
4\end{array}$ \\
\hline Guangdong & 0.2597 & $\begin{array}{l}0.348 \\
4\end{array}$ & $\begin{array}{l}0.384 \\
8\end{array}$ & $\begin{array}{l}0.425 \\
4\end{array}$ & $\begin{array}{l}0.449 \\
2\end{array}$ & $\begin{array}{l}0.457 \\
7 \\
\end{array}$ & $\begin{array}{l}0.333 \\
6 \\
\end{array}$ & $\begin{array}{l}0.317 \\
3 \\
\end{array}$ & $\begin{array}{l}0.488 \\
4\end{array}$ & $\begin{array}{l}0.599 \\
3 \\
\end{array}$ & $\begin{array}{l}0.682 \\
9\end{array}$ & $\begin{array}{l}0.701 \\
4\end{array}$ & $\begin{array}{l}0.741 \\
5 \\
\end{array}$ & $\begin{array}{l}0.793 \\
0\end{array}$ & $\begin{array}{l}0.803 \\
0\end{array}$ & $\begin{array}{l}0.801 \\
5 \\
\end{array}$ \\
\hline East China & 0.3033 & $\begin{array}{l}0.226 \\
6 \\
\end{array}$ & $\begin{array}{l}0.230 \\
4 \\
\end{array}$ & $\begin{array}{l}0.302 \\
5 \\
\end{array}$ & $\begin{array}{l}0.384 \\
5 \\
\end{array}$ & $\begin{array}{l}0.451 \\
8 \\
\end{array}$ & $\begin{array}{l}0.501 \\
8 \\
\end{array}$ & $\begin{array}{l}0.539 \\
9 \\
\end{array}$ & $\begin{array}{l}0.608 \\
6 \\
\end{array}$ & $\begin{array}{l}0.670 \\
5 \\
\end{array}$ & $\begin{array}{l}0.735 \\
1 \\
\end{array}$ & $\begin{array}{l}0.768 \\
6 \\
\end{array}$ & $\begin{array}{l}0.787 \\
8 \\
\end{array}$ & $\begin{array}{l}0.826 \\
3 \\
\end{array}$ & $\begin{array}{l}0.839 \\
4 \\
\end{array}$ & $\begin{array}{l}0.842 \\
9 \\
\end{array}$ \\
\hline Anhui & 0.3557 & $\begin{array}{l}0.187 \\
4\end{array}$ & $\begin{array}{l}0.155 \\
7\end{array}$ & $\begin{array}{l}0.212 \\
7\end{array}$ & $\begin{array}{l}0.249 \\
0\end{array}$ & $\begin{array}{l}0.264 \\
0\end{array}$ & $\begin{array}{l}0.382 \\
5\end{array}$ & $\begin{array}{l}0.431 \\
2\end{array}$ & $\begin{array}{l}0.480 \\
0\end{array}$ & $\begin{array}{l}0.540 \\
4\end{array}$ & $\begin{array}{l}0.592 \\
5\end{array}$ & $\begin{array}{l}0.618 \\
6\end{array}$ & $\begin{array}{l}0.671 \\
7\end{array}$ & $\begin{array}{l}0.685 \\
9\end{array}$ & $\begin{array}{l}0.716 \\
9\end{array}$ & $\begin{array}{l}0.697 \\
4\end{array}$ \\
\hline Jiangxi & 0.1670 & $\begin{array}{l}0.170 \\
1\end{array}$ & $\begin{array}{l}0.176 \\
8\end{array}$ & $\begin{array}{l}0.247 \\
8\end{array}$ & $\begin{array}{l}0.287 \\
8\end{array}$ & $\begin{array}{l}0.333 \\
2\end{array}$ & $\begin{array}{l}0.416 \\
7\end{array}$ & $\begin{array}{l}0.457 \\
4\end{array}$ & $\begin{array}{l}0.502 \\
5\end{array}$ & $\begin{array}{l}0.575 \\
9\end{array}$ & $\begin{array}{l}0.639 \\
3\end{array}$ & $\begin{array}{l}0.665 \\
6\end{array}$ & $\begin{array}{l}0.701 \\
5\end{array}$ & $\begin{array}{l}0.707 \\
6\end{array}$ & $\begin{array}{l}0.715 \\
8\end{array}$ & $\begin{array}{l}0.721 \\
1\end{array}$ \\
\hline Hubei & 0.1877 & $\begin{array}{l}0.165 \\
4\end{array}$ & $\begin{array}{l}0.108 \\
1\end{array}$ & $\begin{array}{l}0.232 \\
8 \\
\end{array}$ & $\begin{array}{l}0.124 \\
2 \\
\end{array}$ & $\begin{array}{l}0.253 \\
4\end{array}$ & $\begin{array}{l}0.358 \\
7 \\
\end{array}$ & $\begin{array}{l}0.414 \\
2 \\
\end{array}$ & $\begin{array}{l}0.461 \\
0\end{array}$ & $\begin{array}{l}0.530 \\
7 \\
\end{array}$ & $\begin{array}{l}0.620 \\
4\end{array}$ & $\begin{array}{l}0.649 \\
6 \\
\end{array}$ & $\begin{array}{l}0.670 \\
2 \\
\end{array}$ & $\begin{array}{l}0.676 \\
6 \\
\end{array}$ & $\begin{array}{l}0.747 \\
3 \\
\end{array}$ & $\begin{array}{l}0.743 \\
4\end{array}$ \\
\hline Hunan & 0.3018 & $\begin{array}{l}0.262 \\
7 \\
\end{array}$ & $\begin{array}{l}0.214 \\
7 \\
\end{array}$ & $\begin{array}{l}0.097 \\
7 \\
\end{array}$ & $\begin{array}{l}0.229 \\
2 \\
\end{array}$ & $\begin{array}{l}0.292 \\
7 \\
\end{array}$ & $\begin{array}{l}0.381 \\
1 \\
\end{array}$ & $\begin{array}{l}0.439 \\
3 \\
\end{array}$ & $\begin{array}{l}0.481 \\
0 \\
\end{array}$ & $\begin{array}{l}0.546 \\
4 \\
\end{array}$ & $\begin{array}{l}0.595 \\
9 \\
\end{array}$ & $\begin{array}{l}0.641 \\
6 \\
\end{array}$ & $\begin{array}{l}0.675 \\
0 \\
\end{array}$ & $\begin{array}{l}0.682 \\
6 \\
\end{array}$ & $\begin{array}{l}0.710 \\
6 \\
\end{array}$ & $\begin{array}{l}0.674 \\
2 \\
\end{array}$ \\
\hline Central China & 0.2531 & $\begin{array}{l}0.196 \\
4\end{array}$ & $\begin{array}{l}0.163 \\
8\end{array}$ & $\begin{array}{l}0.197 \\
7\end{array}$ & $\begin{array}{l}0.222 \\
6\end{array}$ & $\begin{array}{l}0.285 \\
8\end{array}$ & $\begin{array}{l}0.384 \\
8\end{array}$ & $\begin{array}{l}0.435 \\
6\end{array}$ & $\begin{array}{l}0.481 \\
1\end{array}$ & $\begin{array}{l}0.548 \\
4\end{array}$ & $\begin{array}{l}0.612 \\
0\end{array}$ & $\begin{array}{l}0.643 \\
9\end{array}$ & $\begin{array}{l}0.679 \\
6\end{array}$ & $\begin{array}{l}0.688 \\
2\end{array}$ & $\begin{array}{l}0.722 \\
6\end{array}$ & $\begin{array}{l}0.709 \\
0\end{array}$ \\
\hline
\end{tabular}




\begin{tabular}{|c|c|c|c|c|c|c|c|c|c|c|c|c|c|c|c|c|}
\hline Year & 2000 & 2001 & 2002 & 2003 & 2004 & 2005 & 2006 & 2007 & 2008 & 2009 & 2010 & 2011 & 2012 & 2013 & 2014 & 2015 \\
\hline Chongqing & 0.2204 & $\begin{array}{l}0.246 \\
6\end{array}$ & $\begin{array}{l}0.161 \\
2\end{array}$ & $\begin{array}{l}0.289 \\
1\end{array}$ & $\begin{array}{l}0.286 \\
6\end{array}$ & $\begin{array}{l}0.340 \\
2\end{array}$ & $\begin{array}{l}0.332 \\
5\end{array}$ & $\begin{array}{l}0.437 \\
9\end{array}$ & $\begin{array}{l}0.501 \\
6\end{array}$ & $\begin{array}{l}0.542 \\
7\end{array}$ & $\begin{array}{l}0.595 \\
3\end{array}$ & $\begin{array}{l}0.625 \\
4\end{array}$ & $\begin{array}{l}0.651 \\
4\end{array}$ & $\begin{array}{l}0.687 \\
2\end{array}$ & $\begin{array}{l}0.709 \\
9\end{array}$ & $\begin{array}{l}0.701 \\
4\end{array}$ \\
\hline Sichuan & 0.2239 & $\begin{array}{l}0.228 \\
9\end{array}$ & $\begin{array}{l}0.249 \\
0\end{array}$ & $\begin{array}{l}0.310 \\
9\end{array}$ & $\begin{array}{l}0.279 \\
3\end{array}$ & $\begin{array}{l}0.259 \\
3\end{array}$ & $\begin{array}{l}0.318 \\
3\end{array}$ & $\begin{array}{l}0.379 \\
3\end{array}$ & $\begin{array}{l}0.427 \\
2\end{array}$ & $\begin{array}{l}0.545 \\
6\end{array}$ & $\begin{array}{l}0.605 \\
6\end{array}$ & $\begin{array}{l}0.635 \\
2\end{array}$ & $\begin{array}{l}0.655 \\
5\end{array}$ & $\begin{array}{l}0.694 \\
1\end{array}$ & $\begin{array}{l}0.720 \\
5\end{array}$ & $\begin{array}{l}0.703 \\
2\end{array}$ \\
\hline Guizhou & 0.1303 & $\begin{array}{l}0.222 \\
4\end{array}$ & $\begin{array}{l}0.250 \\
5\end{array}$ & $\begin{array}{l}0.248 \\
8\end{array}$ & $\begin{array}{l}0.239 \\
8\end{array}$ & $\begin{array}{l}0.221 \\
3\end{array}$ & $\begin{array}{l}0.296 \\
2\end{array}$ & $\begin{array}{l}0.329 \\
0\end{array}$ & $\begin{array}{l}0.355 \\
1\end{array}$ & $\begin{array}{l}0.427 \\
3\end{array}$ & $\begin{array}{l}0.474 \\
1\end{array}$ & $\begin{array}{l}0.526 \\
6\end{array}$ & $\begin{array}{l}0.560 \\
5\end{array}$ & $\begin{array}{l}0.588 \\
3\end{array}$ & $\begin{array}{l}0.610 \\
5\end{array}$ & $\begin{array}{l}0.606 \\
9\end{array}$ \\
\hline Yunnan & 0.2157 & $\begin{array}{l}0.202 \\
2\end{array}$ & $\begin{array}{l}0.172 \\
0\end{array}$ & $\begin{array}{l}0.171 \\
5\end{array}$ & $\begin{array}{l}0.157 \\
1\end{array}$ & $\begin{array}{l}0.135 \\
7\end{array}$ & $\begin{array}{l}0.121 \\
2\end{array}$ & $\begin{array}{l}0.213 \\
7\end{array}$ & $\begin{array}{l}0.258 \\
2\end{array}$ & $\begin{array}{l}0.336 \\
8\end{array}$ & $\begin{array}{l}0.383 \\
9\end{array}$ & $\begin{array}{l}0.403 \\
8\end{array}$ & $\begin{array}{l}0.452 \\
4\end{array}$ & $\begin{array}{l}0.465 \\
1\end{array}$ & $\begin{array}{l}0.500 \\
3\end{array}$ & $\begin{array}{l}0.489 \\
7\end{array}$ \\
\hline Liaoning & 0.1664 & $\begin{array}{l}0.045 \\
4\end{array}$ & $\begin{array}{l}0.124 \\
4\end{array}$ & $\begin{array}{l}0.094 \\
2\end{array}$ & $\begin{array}{l}0.141 \\
5\end{array}$ & $\begin{array}{l}0.267 \\
4\end{array}$ & $\begin{array}{l}0.350 \\
9\end{array}$ & $\begin{array}{l}0.398 \\
3\end{array}$ & $\begin{array}{l}0.446 \\
1\end{array}$ & $\begin{array}{l}0.490 \\
9\end{array}$ & $\begin{array}{l}0.544 \\
7\end{array}$ & $\begin{array}{l}0.586 \\
8\end{array}$ & $\begin{array}{l}0.603 \\
5\end{array}$ & $\begin{array}{l}0.640 \\
7\end{array}$ & $\begin{array}{l}0.637 \\
7\end{array}$ & $\begin{array}{l}0.627 \\
9\end{array}$ \\
\hline Jilin & 0.2999 & $\begin{array}{l}0.271 \\
0\end{array}$ & $\begin{array}{l}0.237 \\
6\end{array}$ & $\begin{array}{l}0.235 \\
0\end{array}$ & $\begin{array}{l}0.306 \\
5\end{array}$ & $\begin{array}{l}0.346 \\
2\end{array}$ & $\begin{array}{l}0.379 \\
7 \\
\end{array}$ & $\begin{array}{l}0.418 \\
7\end{array}$ & $\begin{array}{l}0.449 \\
7\end{array}$ & $\begin{array}{l}0.474 \\
1\end{array}$ & $\begin{array}{l}0.497 \\
3\end{array}$ & $\begin{array}{l}0.544 \\
3\end{array}$ & $\begin{array}{l}0.528 \\
7\end{array}$ & $\begin{array}{l}0.402 \\
5\end{array}$ & $\begin{array}{l}0.469 \\
0\end{array}$ & $\begin{array}{l}0.463 \\
9\end{array}$ \\
\hline Heilongjiang & 0.1444 & $\begin{array}{l}0.194 \\
5\end{array}$ & $\begin{array}{l}0.115 \\
7\end{array}$ & $\begin{array}{l}0.150 \\
1\end{array}$ & $\begin{array}{l}0.227 \\
0\end{array}$ & $\begin{array}{l}0.261 \\
2\end{array}$ & $\begin{array}{l}0.305 \\
5\end{array}$ & $\begin{array}{l}0.338 \\
7\end{array}$ & $\begin{array}{l}0.384 \\
0\end{array}$ & $\begin{array}{l}0.424 \\
6\end{array}$ & $\begin{array}{l}0.472 \\
3\end{array}$ & $\begin{array}{l}0.501 \\
8\end{array}$ & $\begin{array}{l}0.536 \\
3\end{array}$ & $\begin{array}{l}0.560 \\
9\end{array}$ & $\begin{array}{l}0.579 \\
7\end{array}$ & $\begin{array}{l}0.577 \\
8\end{array}$ \\
\hline
\end{tabular}

\section{B. Results Analysis}

Classification for the coordinated development of urbanization and agricultural modernization in the East China, Central China, West China and Northeast China is made on the basis of ten types of coordinated development shown as the "Table II". Following the time order of 2005,
2010 and 2015, it makes an analysis of its spatial distribution features during the period from the end of the 10th Five-Year Plan to the beginning of the 12th Five-Year Plan[10], which is demonstrated in the "Table IV" and 'Table V'.

TABLE IV. NATIONAL RANKING OF COUPLING COORDINATION DEGREE OF URBANIZATION AND AGRICULTURAL MODERNIZATION

\begin{tabular}{|l|l|l|l|l|l|l|}
\hline \multicolumn{1}{|c|}{ Year } & \multicolumn{1}{c|}{$\mathbf{2 0 0 0 - 2 0 0 5}$ Ranking } & \multicolumn{1}{c|}{ Mean Value } & \multicolumn{2}{c|}{ Ranking } & \multicolumn{2}{c|}{ Mean Value } \\
\hline \multicolumn{1}{|c|}{ Region } & \multicolumn{1}{|c|}{ Mean Value } & \multicolumn{1}{c|}{ Ranking } \\
\hline Jiangsu & 0.2440 & 8 & 0.6464 & 2 & 0.8556 & 1 \\
\hline Zhejiang & 0.3816 & 2 & 0.6988 & 1 & 0.8531 & 2 \\
\hline Fujian & 0.3089 & 3 & 0.6317 & 3 & 0.8079 & 3 \\
\hline Shandong & 0.2607 & 5 & 0.5948 & 4 & 0.7804 & 4 \\
\hline Guangdong & 0.3875 & 1 & 0.4843 & 8 & 0.7681 & 5 \\
\hline Anhui & 0.2374 & 9 & 0.4853 & 7 & 0.6781 & 9 \\
\hline Jiangxi & 0.2305 & 11 & 0.5184 & 5 & 0.7023 & 6 \\
\hline Hubei & 0.1786 & 14 & 0.4770 & 10 & 0.6974 & 7 \\
\hline Hunan & 0.2331 & 10 & 0.4888 & 6 & 0.6768 & 10 \\
\hline Chongqing & 0.2574 & 7 & 0.4820 & 9 & 0.6751 & 11 \\
\hline Sichuan & 0.2586 & 6 & 0.4552 & 11 & 0.6817 & 8 \\
\hline Guizhou & 0.2188 & 12 & 0.3764 & 15 & 0.5786 & 13 \\
\hline Yunnan & 0.1757 & 15 & 0.2628 & 16 & 0.4623 & 16 \\
\hline Liaoning & 0.1399 & 16 & 0.4462 & 12 & 0.6193 & 12 \\
\hline Jilin & 0.2827 & 4 & 0.4439 & 13 & 0.4817 & 15 \\
\hline Heilongjiang & 0.1822 & 13 & 0.3850 & 14 & 0.5513 & 14 \\
\hline
\end{tabular}

First, from the "Table III", we can see in general that from 2000 to 2015, the average degree of nationwide coupling coordination between urbanization and agricultural modernization increases from 0.1612 to 0.7333 and it has experienced a transition from high-level imbalance to moderate coupling coordination, indicating that great improvements have been made in the coordinated development between urbanization and agricultural modernization. To be specific, there were 13 provinces and 3 provinces which respectively suffer imbalance and low-level coordination between urbanization and agricultural modernization in 2005; in 2010, one province was involved in imbalance, 7 provinces in low-level coordination and 8 provinces in moderate coordination; in 2015, the number of provinces experiencing imbalance, low-level coordination, moderate coordination and high-level coordination is respectively zero, three, eight and five, all of which indicate a optimization trend. However, the facts should never be neglected that overall function and development of urbanization and agricultural modernization are still not sound; coupling coordination degree fails to reach 0.8 ; great potentials are harbored in the coordinated development between urbanization and agricultural modernization. For example, in 2015 imbalance has disappeared among 16 provinces but regions with quality coupling coordination is not coming into being.

Second, difference of coordination level between urbanization and agricultural modernization is relatively obvious and its spatial distribution is imbalanced. As it is shown in the Table 3 and 4, during the investigation period, 
regions in East China have high coupling coordination and play a leading role in the coordinated development of urbanization and agricultural modernization such as Jiangsu, Zhejiang, Fujian, Shandong and Guangdong. By contrast, coupling coordination is relatively lower in the provinces of Guizhou, Yunnan, Jilin and Heilongjinag at the stage of lowlevel coordination while concerning growth speed, they come out in front. For example, Guizhou Province and Heilongjiang Province have a growth rate of 10.8 percent and 9.68 percent, respectively ranking No.1 and No. 4 nationwide.

Inspired by the above results, it divided the whole economic regions into four part including east China, Central China, West China and Northeast China so as to reflect social and economic development in those regions in a scientific way. According to the "Fig. 1", during the investigation period, the coupling coordination of these four major regions rises year by year and shows such distribution featuring "top in East China and gradually lowering in the West China and then Northeast China". Economic development in real term among various regions reveals that coordination degree of agricultural modernization has a positive correlation with their economic development. Specifically, regions with stronger economic development show higher coordination between urbanization and agricultural modernization, which is totally in line with basic economic theories. We think that the degree of coordination between urbanization and agricultural modernization substantially presents allocation ability of urban and rural factor resources, which means that a region with sounder coordination is strong in the ability of reasonable allocation and its economic balance, inclusiveness and sustainability is correspondingly growing. That is why the Park Central Committee takes "coordination" as one of the five major development theories.

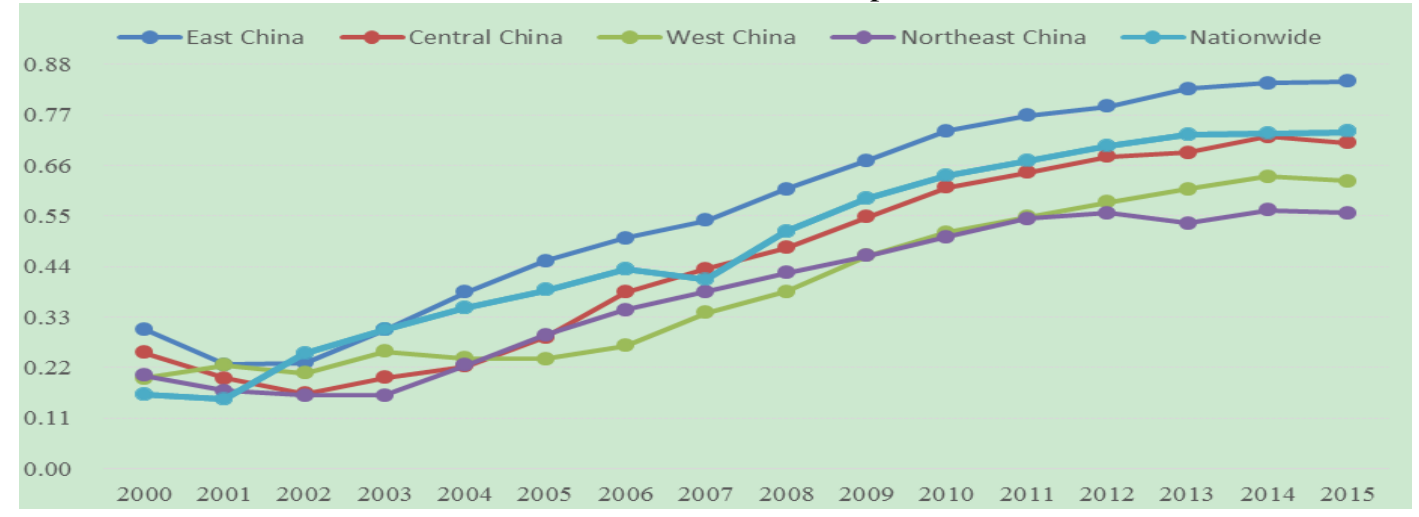

Fig. 1. Chapter 1 Analysis of Nationwide Coordination Degree of Urbanization and Agricultural Modernization.

TABLE V. SPATIAL Distribution PATTERn OF NATIONWIDE COORDINATION DEVELOPMENT OF URBANIZATION AND AGRICULTURAL MOdERNIZATION

\begin{tabular}{|c|c|c|c|c|c|c|c|c|}
\hline Type & Range & Sub-type & 2005 & $\begin{array}{c}\text { Spatial } \\
\text { Distribution }\end{array}$ & 2010 & $\begin{array}{c}\text { Spatial } \\
\text { Distribution }\end{array}$ & 2015 & $\begin{array}{c}\text { Spatial } \\
\text { Distribution }\end{array}$ \\
\hline \multirow{4}{*}{ Imbalance } & $0.0-0.1$ & $\begin{array}{l}\text { Extremely } \\
\text { Imbalanced Decay }\end{array}$ & Null & Null & Null & Null & Null & Null \\
\hline & $0.1-0.2$ & $\begin{array}{l}\text { High-level } \\
\text { Imbalanced Decay }\end{array}$ & Yunnan & West 1 & Null & Null & Null & Null \\
\hline & $0.2-0.3$ & $\begin{array}{l}\text { Moderate } \\
\text { Imbalanced Decay }\end{array}$ & $\begin{array}{l}\text { Anhui, Hubei, } \\
\text { Hunan, Sichuan, } \\
\text { Guizhou, Liaoning, } \\
\text { Heilongjiang }\end{array}$ & $\begin{array}{l}\text { Central } 3 \\
\text { West } 2 \\
\text { Northeast } 2\end{array}$ & Null & Null & Null & Null \\
\hline & $0.3-0.4$ & $\begin{array}{l}\text { Low-level } \\
\text { Imbalanced Decay }\end{array}$ & $\begin{array}{l}\text { Jiangsu, Shandong, } \\
\text { Jiangxi, Chongqing } \\
\text { Jilin }\end{array}$ & $\begin{array}{l}\text { East } 2 \\
\text { Central } 1 \\
\text { West } 1 \\
\text { Northeast } 1 \\
\end{array}$ & Yunnan & West 1 & Null & Null \\
\hline \multirow[b]{2}{*}{$\begin{array}{l}\text { Low-level } \\
\text { Coordination }\end{array}$} & $0.4-0.5$ & $\begin{array}{l}\text { On the Verge of } \\
\text { Imbalanced Decay }\end{array}$ & Fujian, Guangdong & East 2 & $\begin{array}{l}\text { Guizhou, Jilin, } \\
\text { Heilongjiang }\end{array}$ & $\begin{array}{l}\text { West } 1 \\
\text { Northeast } 2\end{array}$ & Yunnan, Jilin & $\begin{array}{l}\text { West } 1 \\
\text { Northeast } 1\end{array}$ \\
\hline & $0.5-0.6$ & $\begin{array}{l}\text { Forced Coupling } \\
\text { Coordination }\end{array}$ & Zhejiang & East 1 & $\begin{array}{l}\text { Anhui, } \\
\text { Liaoning, } \\
\text { Hunan, } \\
\text { Chongqing }\end{array}$ & $\begin{array}{l}\text { Central 2 } \\
\text { West } 1 \\
\text { Northeast } 1\end{array}$ & Heilongjiang & Northeast 1 \\
\hline \multirow{2}{*}{$\begin{array}{l}\text { Moderate } \\
\text { Coordination }\end{array}$} & $0.6-0.7$ & $\begin{array}{l}\text { Primary Coupling } \\
\text { Coordination }\end{array}$ & Null & Null & $\begin{array}{l}\text { Shandong, } \\
\text { Hubei, } \\
\text { Sichuan,Jiangxi, } \\
\text { Guangdong }\end{array}$ & $\begin{array}{l}\text { East } 2 \\
\text { Central } 2 \\
\text { West } 1\end{array}$ & $\begin{array}{l}\text { Anhui, Hunan, } \\
\text { Guizhou, Liaoning }\end{array}$ & $\begin{array}{l}\text { Central } 2 \\
\text { West } 1 \\
\text { Northeast } 1\end{array}$ \\
\hline & $0.7-0.8$ & $\begin{array}{l}\text { Moderate } \\
\text { Coupling } \\
\text { Coordination } \\
\end{array}$ & Null & Null & $\begin{array}{l}\text { Jiangsu, } \\
\text { Zhejiang, Fujian }\end{array}$ & East 3 & $\begin{array}{l}\text { Jiangxi, } \\
\text { Chongqing, } \\
\text { Hubei, Sichuan }\end{array}$ & $\begin{array}{l}\text { Central } 2 \\
\text { West } 2\end{array}$ \\
\hline
\end{tabular}




\begin{tabular}{|c|c|c|c|c|c|c|c|c|}
\hline Type & Range & Sub-type & 2005 & $\begin{array}{c}\text { Spatial } \\
\text { Distribution }\end{array}$ & 2010 & $\begin{array}{c}\text { Spatial } \\
\text { Distribution }\end{array}$ & 2015 & $\begin{array}{c}\text { Spatial } \\
\text { Distribution }\end{array}$ \\
\hline High-level & $0.8-0.9$ & $\begin{array}{l}\text { Good Coupling } \\
\text { Coordination }\end{array}$ & Null & Null & Null & Null & $\begin{array}{l}\text { Jiangsu, Shandong, } \\
\text { Zhejiang, Fujian, } \\
\text { Guangdong }\end{array}$ & East 5 \\
\hline
\end{tabular}

\section{Convergence Test}

From the above analysis, it can be seen that there are regional disparities in the coupling coordination degree between urbanization and agricultural modernization in each province.

In order to better explain the space-time disparity, convergence test of the coupling coordination degree is conducted, and characteristics and regularities of the disparities are thereby obtained. Barro $\beta$ convergence and $\sigma$ convergence are the two most effective methods in many convergence test methods. $\sigma_{\text {value is mainly used to }}$ measure the difference between regions based on the degree of dispersion between variables. If $\sigma_{t+1}<\sigma_{t}$, the convergence is achieved, which shows that the gap of coupling degree between provinces is narrowing. Otherwise, it is widening. $\beta$ Convergence mainly focuses on the correlation between the development process and the initial development level of a variable within the test region. That is to say, it studies the negative correlation between the development speed of the coupling coordination degree and the initial coupling coordination development level in a region, which cannot be used to measure the disparity of coupling coordination degree between regions. Therefore, $\sigma$ convergence is used in this paper to measure the dispersion of coupling coordination degree between urbanization and agricultural modernization in each region, and its test formula is as follows:

$$
\sigma_{i}=\left\{N^{-1} \sum_{m=1}^{N}\left[X_{m}(t)-\left[N^{-1} \sum_{i=1}^{N} X_{i}(t)\right]\right]^{2}\right\}^{\frac{1}{2}}
$$

In the formula, $X_{m}(t)$ indicates the coupling degree of the $\mathrm{m}$ province in the year of $\mathrm{t} . \mathrm{t}=(2000,2001, \ldots, 2015)$. $N(\mathrm{~N}=16)$ signifies the number of provinces[11].

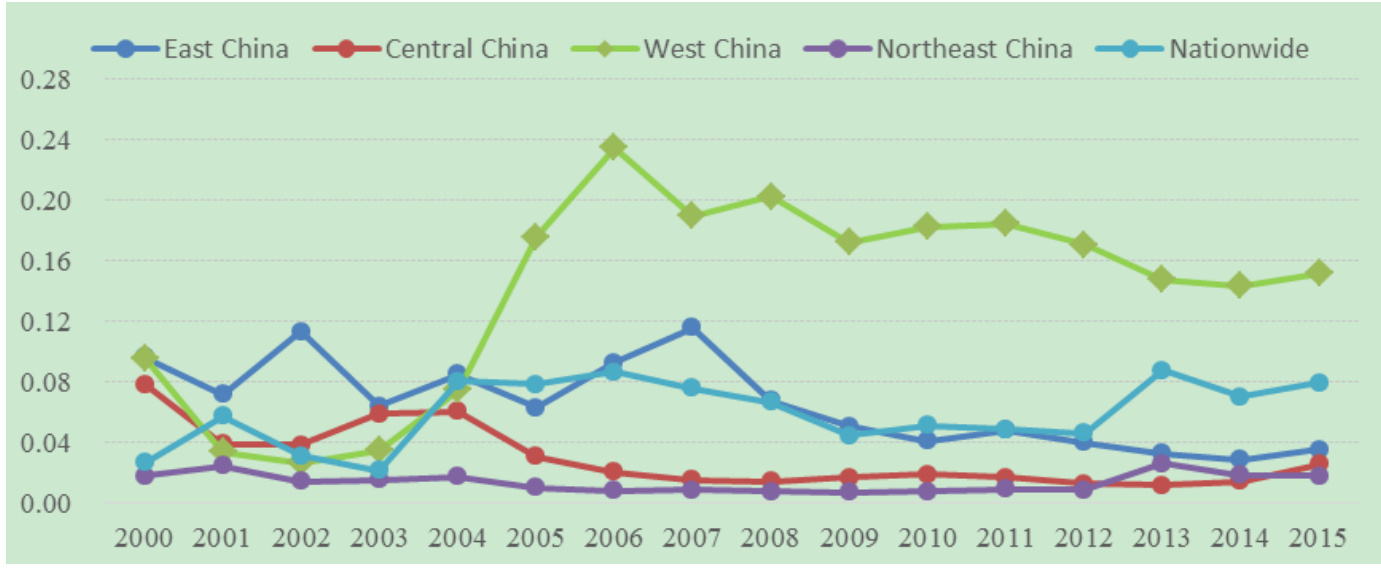

Fig. 2. Convergence Test Chart of Nationwide of the Coordination Degree of Urbanization and Agricultural Modernization.

According to "Fig. 2", as a whole, $\sigma$ value of coupling coordination degree between urbanization and agricultural modernization is relatively stable and convergent with small fluctuation during 2000-2015, which firmly shows that the construction of urban-rural integration in China has achieved remarkable results, and the gap of coupling coordination degree between urbanization and agricultural modernization is narrowing.

From the regional perspective, during the inspection period, $\sigma$ value of the coupling coordination degree in the eastern region is the closest to the national value, which shows that disparity variation of the coupling coordination degree in the eastern is the most important one for the whole nation. Variation trends of $\sigma$ value in the central and northeastern regions are similar. With the year of 2012 as the watershed, during 2000-2012, $\sigma$ value of the coupling coordination degree of the central was higher than of the northeast. However, after $2012, \sigma$ value of the central was lower than of the northeast, and the convergent trend appeared. Disparity variation of the coupling coordination degree in the western region is the biggest. In 2000-2003, $\sigma$ value of the coupling coordination degree decreased gradually, while in 2003-2006, it increased rapidly. In $2006-2015, \sigma$ value of the coupling coordination degree increased and decreased alternately, the disparity variation narrows and the convergent trend appeared.

\section{CONCLUSION}

Differentiate regional differences and implement precise and intensive measures. The relation between agricultural modernization and urbanization is positively correlated with the gradient of economic development in eastern and western 
regions. In the economically developed regions, it is a priority to seek a higher level of coordination degree of urbanization and agricultural modernization, to improve the agricultural labor productivity and the land productivity on the basis of a better development of agricultural modernization, to speed up the interconnection between cities and towns, and to improve the level of public services; In the central region, the new function of modern agriculture should be expanded while strengthening the urban function construction; In the fragile areas of western China, efforts should be put on the development of urbanization with regional characteristics based on the characteristic agricultural development. At the same time, in the areas where the agricultural modernization and the urbanization coordination are better, we are supposed to further expand new types of agriculture, focus on the development of urban agriculture so as to lay a foundation for urban ecological coordination and to consolidate the basis of a coordinated development of urbanization and agricultural modernization.

Construct the system foundation of urban and rural equalized development. It is wise to actively construct the system mechanism of urban and rural equalized development and lay a solid system basis for the harmonious development of agricultural modernization and urbanization. We are supposed to continue to deepen the policy of benefiting agriculture, adhere to the policy framework of industrial feedback and township, so that farmers can participate in the marketization process equally and enjoy the fruits of reform and opening-up. The two-way interaction of economic elements in agriculture and non-agricultural industry should be accelerated. Through the effective urbanization construction, we should change the one-way flow mode of economic elements in non-agricultural industry, actively guide and drive the modern production elements, such as capital, technology, information and talents, to accumulate in agricultural and rural area so as to form the two-way interaction, and finally realize the equal exchange of urban and rural elements. More importantly, we should abandon the logical framework of urban centrality in the aspects of infrastructure and public services to realize the equalization of public services and construct a new type of relationship between farmers and workers, the urban and the rural.

Embody regional characteristics in the coordinated development of agricultural modernization and urbanization. On the one hand, we should accelerate the orderly transfer of surplus rural labor, effectively change the contradiction between people and land, and lay a foundation for the development of moderate scale operation, the innovation of agricultural industry organization and the increase of productivity and land output rate, thus promoting the development of urbanization; On the other hand, we must push forward the development of agricultural modernization, strengthen vertical and horizontal integration of agriculture, provide practical industrial support and create more job opportunities for the urbanization process, and realize the continuation and transfer of surplus rural labor. However, different regions have different resources and industrial structures. As a result, in the process of seeking coordinated development, we should promote the modernization of agriculture according to regional characteristics; abandon the same urbanization development of different regions. That is, the industrial development foundation should be combined to strengthen the construction of characteristic agricultural town, promote the development of new characteristic urbanization, and realize a higher coordinated level of agricultural modernization and urbanization.

\section{REFERENCES}

[1] Cui Huixia. Study on the Simultaneous Development of Industrialization, Urbanization and Agricultural Modernization [J].The World of Survey and Research, 2012, (06):45-49.

[2] Zhao Hong. Promote Simultaneous and Coordinated Development of Urbanization and Agricultural Modernization[N]. Farmers' Daily, 2012-12-04 (003).

[3] Hu Xiaoqun, Shen Qi, Xu Gongwei. Evaluation and Analysis of Coordination Degree Between Urbanization and Agricultural Modernization--A Case Study of Five FunctionalAreas in Chongqing $[\mathrm{J}]$. Chinese Journal of Agricultural Resources and Regional Planning, 2015, (04): 16-22.

[4] Heng Jie. Study on the Relationship between New Urbanization and Agricultural Modernization in Anhui Province [J]; Journal of Anhui University of Finance and Economics, 2014.

[5] Hou Pei, Yang Qingyuan, He Jian, Min Jie. Evaluation and Study of Coupling Coordination between Urbanization and Ecological Environment Development--A Case Study of 38 Counties in Chongqing [J]. Journal of Southwest China Normal University (Natural Science Edition) 2014, (02): 80-86.

[6] Zhu Dianxiao, Hu Zhiquan. Analysis of the Coordinated Development Degree of Urbanization and Agricultural Modernization [J]. Chinese Agricultural Science Bulletin, 2015, (26): 285-290.

[7] Chen Jichun, Chen Zhongnuan. Study on the Coupling Coordination Between China's Real Estate Industry and Regional Economy [J]. Commercial Research, 2011, (04):112-117.

[8] Wang Yifu. Comprehensive Evaluation and Analysis of the Coordinated Development Level of Industrialization, Urbanization and Agricultural Modernization in Heilongjiang Reclamation Area [D]. Heilongjiang Bayi Agricultural University, 2013.

[9] Deng Chuxiong, Xie Binggeng, Wu Yongxing, Li Xiaoqing, Fu Lihua.Quantitative Comprehensive Evaluation of Sustainable Development of Urban Agriculture in Shanghai [J]. Journal of Natural Resources, 2010 (9): 1577-1588

[10] Han Guoming, Zhang Hengming.Study on the Spatial Distribution Disparity of Coordinated Development of New Urbanization and Agricultural Modernization in China [J]. Jilin University Journal Social Sciences Edition, 2015, (05): 36-46 + 172.

[11] Qian Li, Chen Zhongwei, Xiao Renqiao.Study on the Coupling Coordination Degree ofChina's Regional Industrialization, Urbanization and Agricultural Modernization and Its Influencing Factors [J]. Inquiry into Economic Issues, 2012, (11): 10-17. 